\title{
Assessing stress at work: The Portuguese version of the Job Content Questionnaire
}

\author{
Madalena Vilas-Boas ${ }^{1}$, Alzira Cerqueira \\ Universidade Fernando Pessoa, Porto, Portugal
}

\section{ABSTRACT}

The aim of this paper was to study one of the most important tools for assessing the psychosocial factors underlying stress at work. The study of the Portuguese version of the Karasek's Job Content Questionnaire (JCQ) also intends to contribute to the discussion about the theoretical model (the division of the decision latitude in one or two dimensions) and the scale itself (the adequacy of the items from the Psychological Job Demand Scale). Construct validity of the questionnaire was examined using an exploratory factor analysis (maximum likelihood with promax rotation). After deleting three items, the analysis found a four-factor model. The reliability was estimated with Cronbach's alpha, indicating appropriate internal consistency for three scales and problems for psychological job demands. The findings suggest that the psychometric properties of the Portuguese version of the JCQ are satisfactory, although further improvement is needed for the psychological job demands scale. The results do not support the theoretical decision of dividing the decision latitude scale into two dimensions.

Keywords: Job Content Questionnaire; work stress; psychosocial work factors; organizational risk factors; Portugal.

\section{RESUMO - Avaliação do estresse no trabalho: a versão portuguesa do Job Content Questionnaire}

O objetivo deste trabalho foi averiguar uma das ferramentas mais importantes para avaliar os fatores psicossociais e organizacionais subjacentes ao estresse no trabalho. O estudo da versão portuguesa do Job Content Questionnaire (JCQ), de Karasek, visa também contribuir para a discussão sobre a divisão da latitude de decisão em uma ou duas dimensões e sobre a adequação dos itens da escala exigências psicológicas do trabalho. A validade de construto foi avaliada por meio da análise fatorial exploratória, pelo método máxima probabilidade, com rotação promax. Depois de retirados três itens, foi encontrado um modelo de quatro fatores. O alfa de Cronbach mostrou que apenas a escala exigências psicológicas apresentava problemas de consistência interna. Os resultados sugerem que as propriedades psicométricas da versão portuguesa do JCQ são satisfatórias, embora seja ainda necessário melhorar a escala de exigências psicológicas. Os resultados não apoiam a decisão teórica de dividir a latitude em duas dimensões.

Palavras-chave: Job Content Questionnaire; estresse no trabalho; fatores psicossociais do trabalho; fatores organizacionais de risco; Portugal.

\section{RESUMEN - Evaluación del estrés laboral: versión portuguesa del Job Content Questionnaire}

El objetivo de este trabajo es el estudio de una de las herramientas más importantes para evaluar los factores psicosociales y organizacionales subyacentes al estrés en el trabajo. El estudio de la versión portuguesa del Job Content Questionnaire (JCQ) de Karasek tiene también por finalidad contribuir a la discusión sobre la división de la latitud de decisión en una o dos dimensiones y sobre la adecuación de los ítems de la escala demanda psicológica del trabajo. La validez de constructo del cuestionario se examinó mediante análisis factorial exploratorio, por el método máxima probabilidad con la rotación Promax. Después de eliminar tres variables, el análisis encontró un modelo de cuatro factores. El alfa de Cronbach mostró que apenas la escala exigencias psicológicas presentaba problemas de consistencia interna. Los resultados sugieren que las propiedades psicométricas de la versión portuguesa del JCQ-PT son satisfactorias, aunque es necesario mejorar la escala de demandas psicológicas. Los resultados no apoyan la decisión teórica de dividir la latitud en dos dimensiones.

Palabras clave: Job Content Questionnaire; estrés en el trabajo; factores psicosociales del trabajo; factores de riesgo de la organización; Portugal.

\section{Introduction}

The increased globalization, with the rising competition, unemployment, and continuous change, is pressing companies, public services and individuals to work more and better with fewer resources and in a context of scary insecurity. The stress related to work is one of the results of this situation. In fact, the stress related to work is becoming a significant problem worldwide, with big costs to individuals, organizations and society as a whole. Stress happens when there is a perception of a persistent imbalance between demands and available resources to cope with them. When stress levels are high for a long time, it may cause physical and psychological ill-health (Engström, Ljunggren, Lindqvist, \& Carlsson, 2006; Hush, Michaleff, Maher, \& Refshauge, 2009; Stansfeld, \& Candy, 2006). 
In order to identify the chronic stressors, we need a conceptual framework that elicits the characteristics in organizations that are involved in work stress.

The Job Demand-Control model, developed by Karasek (1979), is a major theoretical model, widely used in studies of occupational or work-related stress (Van der Doef, \& Maes, 1999). It results from the combination of two lines of research dealing with the relation between psychosocial work characteristics and well-being (and even physical and mental health). This model predicts that job strain is the result of an interaction between psychological job demands and decision latitude (or job control). In other words, job strain exists if job demands exceed decision latitude.

Psychological job demands measures stress factors related to organizational constraints on task completion (like having enough time to get the job done) and conflicting demands on the job. Job decision latitude is a combination of two empirically related, but theoretically distinct constructs: the worker's freedom to make decisions (decision authority), and the spread of skills that the worker uses on the job (skill discretion). According to the model, a high level of skill gives the individual a sense of authority or control over their work activities. This possibility of making decisions will reduce possible adverse effects of psychological job demands.

In a later development (Johnson, Hall, \& Theorell, 1989), the model has been extended, and the social support dimension was added because many studies have found stress has a greater health effect among workers with low-social support (Landsbergis, Schnall, Dietz, Friedman, \& Pickering, 1992), resulting in the job demand-control-support (JDCS) model. Social support refers to the helpful social interactions available on the workplace from supervisors and co-workers, and it is believed to act as a mediator of work stress (Sale, \& Kerr, 2002). In fact, the buffer hypothesis states that a support level above a certain threshold protects against the negative impact of high strain (Sanne, Mykletum, Dahl, Moen, \& Tell, 2005). The JDCS model is a major theoretical model widely used in studies of occupational or work-related stress. This model predicts that the perceived job strain is the result of an interaction between psychological job demands, control and social support. So, the most adverse health effects are to be expected in jobs that combine high job demands, low control and low-worksite support (high strain jobs). The literature provides considerable support to the main aspects of the model (Choi et al., 2008; Lange, Taris, Kompier, \& Houtman, 2003; Niedhammer, Chastang, Gendrey, David, \& Degioanni, 2006; Pelfrene et al., 2001; Sanne et al., 2005).

Job strain as conceptualized in Karasek's model is usually measured by the Job Content Questionnaire (JCQ) (Karasek, 1985), one of the most popular self-administered instruments used to measure the psychosocial work environment. The main items of the JCQ were taken from the United States quality of employment surveys (Santavirta, 2003). The three dimensions of the model are measured by the scales: psychological job demands, decision latitude (skill discretion and decision authority), co-worker support and supervisory support. Several versions of the JCQ exist. Some versions have more dimensions (like job dissatisfaction or physical job demands) and some have less. The test has been translated into over two dozen languages and standardized in many countries (Alves, Chor, Faerstein, Lopes, \& Werneck, 2004; Araújo, \& Karasek, 2008; Edimansyah, Rusli, Naing, \& Mazalisah, 2005; Hoang, Corbière, Negrini, Pham, \& Reinharz, 2013; Kawakami, Kobayashi, Araki, Haratani, \& Furui, 1995; Niedhammer et al., 2006; Ortiz, 2011; Pelfrene et al., 2001; Sanne et al., 2005).

The studies that tested JCQ reliability and validity (mostly, decision latitude, psychological job demands, supervisor support, and co-worker support scales) have generally found acceptable psychometric characteristics and substantial comparability of the JCQ scales across populations (Choi et al., 2009; Fransson et al., 2012; Jabali et al., 2013), despite some exceptions, as is the case of the psychological job demands scale, that shows low internal consistency in some studies (Kawakami et al., 1995; Phakthongsuk, \& Apakupakul, 2008). The studies also found different results in the decision latitude scale that can challenge the theoretical framework: some identify two factors in that scale - skill discretion and decision authority (Chien et al., 2011; Karasek et al., 1998; Smith, Tisak, Hahn, \& Schmieder, 1997) —, and others only one factor (Niedhammer et al., 2006; Pelfrene et al., 2001; Phakthongsuk, \& Apakupakul, 2008; ZotnierczykZreda, \& Bedyriska, 2014).

In Portugal, as in many other countries, most job stress studies use measures that lack adequate validation, mainly in the Portuguese version. So, the validation of a JCQ Portuguese version seems crucial to the assessment of the psychometric properties of the instrument utilized in Portugal and its use in international comparisons between studies.

Therefore, one of the main objectives of the present study was to perform an exploratory study of one version of the JCQ in a Portuguese working population. Taking into account the problems found in some studies, another goal was to contribute to the discussion about the appropriateness of psychological demands scale items (Kawakami et al., 1995; Phakthongsuk, \& Apakupakul, 2008) and about the one or two dimensions of the decision latitude scale.

With Karasek's permission, we translated 22 items, selected from the full version of the JCQ scales, into Portuguese, measuring four scales: decision latitude, psychological job demands, supervisor support, and coworker support. 


\section{Method}

\section{Participants}

A cross-sectional study was conducted with people living in Portugal, from 22 major occupational categories, and from a broad range of organizations. Of the 1,897 questionnaires distributed, 1,192 were collected - the response rate was $63 \%$. One hundred twenty-six ones were rejected because they were incomplete. The study population comprised 1,066 participants, 426 males (40\%) and 640 females $(60 \%)$. Most of the individuals $(69 \%)$ were 30 years old or younger $(34 \%)$, or 31 to 40 years old $(35 \%)$. Only $9.4 \%$ were older than 50 years old, and $49.5 \%$ of the individuals had university education, a much high level of education than that of the general Portuguese working population $(20 \%)$. This "education inflation" may be related to the kind of respondents that are generally available to collaborate on studies with self-administrated scales: people with ease in interpreting texts and accustomed to such situations. Albeit participants were classified into 22 major occupational groups, there was an emphasis on services and professional workers. Only $38.8 \%$ were executive workers. Although the sample cannot be considered representative of the Portuguese workforce, it can be expected to contain a desirable variation of exposure to job stress, which is needed in an exploratory study.

\section{Instrument}

The chosen scales from the JCQ (Karasek, 1985) were translated into Portuguese and then retranslated into English by a Britain native and bilingual speaker who was unaware of the original English version. Both English versions were very similar, so we can consider that a good translation was made.

The Portuguese version of the JCQ contains 22 items. Each item asks the individual's perception about his/her job, supervisor or colleagues:

- Decision latitude: "learn new things" (SD1) ("my job requires that I learn new things"), "repetitive work" (SD2), "creativity" (SD3), "high skill" (SD4), "variety" (SD5), "develop own abilities" (SD6) - skill discretion; "allow own decisions" (DA1), "lot to say" (DA2), "little decision freedom" (DA3) - decision authority;

- Psychological job demands: "conflicting demands" (PD1), "work fast" (PD2), "work hard" (PD3), "no excessive work" (PD4), "enough time" (PD5);

- Supervisor support: "concerned" (SS1), "pays attention" (SS2), "helpful” (SS3), "good organizer" (SS4);

- Co-worker support: "competent" (CS1), "interested" (CS2), "friendly" (CS3), "helpful” (CS4).

In all four scales, the response grading is intensity-based. Each item is scored on a four-point Likert scale, corresponding to the four response categories, ranging from 1 or "strongly disagree" to 4 or "strongly agree". Information on sex, age, education level, and job title was also obtained.

\section{Procedure}

The participants selection was non probabilistic. All members on the targeted population were invited through personal contact or internal communications of their organizations.

As the questionnaires were self-administered, they were distributed directly to the subjects or by their managers. Each questionnaire had an attached letter explaining its objectives and guaranteeing confidentiality. A pre-paid envelope for returning the filled questionnaire was also distributed to each participant, granting, this way, total anonymity. In all the procedures, the principles established in the American Psychological Association (APA) Code of Ethics (2002) were observed.

\section{Statistical analysis}

Data entry and analysis were done by the Statistical Package for the Social Sciences (SPSS) (version 23). To access the construct validity and to compare the factor structure of this JCQ version to that of the original JCQ, the Exploratory Factorial Analysis (EFA) was chosen. This procedure has the advantage of counting only the common variance when determining factors (Damásio, 2012). Before the EFA, the data's fit to factoring was assessed by using the Kaiser-Meyer-Olkin criterion (the cut-off was 0.7) and the Bartlett's test of sphericity $(\mathrm{p}<0.05)$. To choose the extraction method, the normality of the data was evaluated with the Kolmogorov-Smirnov test. As the test showed that the scores obtained for the scale were normally distributed $(0.04, p=0.000)$, the data were factorized with the Maximum Likelihood method (ML) (Damásio, 2012). The criterion to factors' retention was the KaiserGuttman (eigenvalue $>1$ ). To improve the accuracy of this criterion, when items had low saturation in a factor, the parallel analysis (PA) was used: only factors with eigenvalues higher than one, and higher than the respective eigenvalue obtained through random data (generated by the site http://ires.ku.edu/ smishra/parallelengine.htm) were retained (Damásio, 2012). To maximize the saturation of the items in the respective factors and make the factorial loads easier to interpret, we proceeded to the rotation of factors (Hill, \& Hill, 2000) using the promax method, since it has accurate results even if the factors were correlated (Damásio, 2012). With this procedure, it appeared a factorial structure in which one and only one of the original variables is strongly associated with a unique factor, generating a new set of weights of items for every component, keeping stable the proportion of variance explained by each component (Maroco, 2003). Only items loading greater than 
0.40 were considered meaningful loadings on a factor (Hill, \& Hill, 2000).

In order to evaluate how strong the relations between items, items/scales and scales were, Pearson's correlation coefficients between items and scales scores were calculated. A value of less than 0.30 indicates low correlation (Nunnally, \& Bernstein, 1994).

For the scale and each sub-scale, their internal consistency or reliability was evaluated by Cronbach's alpha coefficients (Nunnally \& Bernstein 1994). We can consider the scale to be reasonably consistent, i.e., the questions aimed at measuring the same construct, if the coefficient was higher than 0.70 (Nunnally \& Bernstein, 1994).

\section{Results}

\section{Construct validity}

Exploratory analysis

The Kaiser-Meyer-Olkin criterion $(\mathrm{KMO}=0.86)$ and the Bartlett's test of sphericity $\left(\chi^{2}=8406\right.$; $\mathrm{df}=231 ; \mathrm{p}=0.000)$ showed that data can be factorized. The ML analysis and the PA analysis identified six factors. The variance explained by the six factors considered is adequate (63\%). Factors 1 and 6 grouped all the items connected with decision latitude, except for "repetitive work" (skill discretion subscale) and "little decision freedom" (decision authority subscale). Those two items did not load in any factor. The items related to the psychological job demands were also divided into two factors: two items loaded in factor 4 and one in factor 5 . Two items ("conflicting demands" and "no excessive work") did not load in any factor. Factors 2 and 3 grouped all the items connected to supervisor support and co-worker support, respectively.

Two of the scales presented the same number of factors as in the original JCQ (supervisor support and co-workers support). In the psychological job demands scale, two factors were found, while the original JCQ found only one. In the decision latitude scale, two factors were found, as could be expected, but they were not the anticipated ones: skill discretion and decision authority, because the items of those expected subscales were mixed in both factors.

In an analysis with the number of factors limited to four (those expected by the model), the results were more similar to those expected. The items from the decision latitude scale loaded in factor 1 , supervisor support in factor 2, co-workers support in factor 3, and psychological job demands in factor 4 . Nevertheless, the variance explained was smaller $(52 \%)$, and there were three items ("repetitive work", "work hard" and "excessive work") that did not load in any factor.
After the deletion of the three items whose results were different from those expected, an analysis without a pre-determined number of factors was done. There were suitable values of KMO (0.87) and Bartlett's test $\left(\chi^{2}=7827 ; \mathrm{df}=171 ; \mathrm{p}=0.000\right)$. This analysis gave rise to a four-factor structure that completely corresponded to the four scales, and explained $58.6 \%$ of variance (Table 1). All eigenvalues had higher values than those from the random data $(5.35>1.24 ; 2.49>1.20 ; 1.95>1.17 ; 1.35>1.13)$. The items from the decision latitude scale loaded in factor 1 (eight items), supervisor support in factor 2 (four items), co-workers support in factor 3 (four items), and psychological job demands in factor 4 (three items).

Table 1

Factor analysis after deleting three items

\begin{tabular}{|c|c|c|c|c|c|}
\hline & \multicolumn{4}{|c|}{$\begin{array}{l}\text { Factors with the } \\
\text { 19-items version }\end{array}$} & \multirow{2}{*}{ Communalities } \\
\hline & $\mathrm{F} 1$ & $\mathrm{~F} 2$ & F3 & F4 & \\
\hline SD1 & 0.62 & & & & 0.39 \\
\hline SD2 & - & - & - & - & - \\
\hline SD3 & 0.67 & & & & 0.46 \\
\hline SD4 & 0.61 & & & & 0.37 \\
\hline SD5 & 0.65 & & & & 0.32 \\
\hline SD6 & 0.78 & & & & 0.61 \\
\hline DA1 & 0.74 & & & & 0.55 \\
\hline DA2 & 0.53 & & & & 0.32 \\
\hline DA3 & 0.61 & & & & 0.41 \\
\hline PD1 & & & & 0.51 & 0.30 \\
\hline PD2 & & & & 0.73 & 0.41 \\
\hline PD3 & - & - & - & - & - \\
\hline PD4 & - & - & - & - & - \\
\hline PD5 & & & & 0.95 & 0.91 \\
\hline SS1 & & 0.84 & & & 0.71 \\
\hline SS2 & & 0.88 & & & 0.78 \\
\hline SS3 & & 0.81 & & & 0.65 \\
\hline SS4 & & 0.77 & & & 0.59 \\
\hline CS1 & & & 0.65 & & 0.42 \\
\hline CS2 & & & 0.80 & & 0.64 \\
\hline CS3 & & & 0.85 & & 0.72 \\
\hline CS4 & & & 0.77 & & 0.60 \\
\hline Eigenvalues & 5.35 & 2.49 & 1.95 & 1.35 & \\
\hline $\begin{array}{l}\text { Variance } \\
\text { explained (\%) }\end{array}$ & 28.2 & 13.1 & 10.2 & 7.1 & \\
\hline $\begin{array}{l}\text { Variance } \\
\text { explained - } \\
\text { accumulated (\%) }\end{array}$ & 28.2 & 41.3 & 51.5 & 58.6 & \\
\hline
\end{tabular}

Note: $\mathrm{SD}=$ skill discretion; $\mathrm{DA}=$ decision authority; $\mathrm{PD}=$ psychological demands; SS: supervisors support; $C S=$ =co-workers support; $F=$ factor. 


\section{Internal consistency}

In order to evaluate the degree of correlation between each item and its respective dimension, the correlation item-scale was calculated. All items correlated to their scale, which showed that every item contributed to the scale variance. The exception was the item "work fast" (PD2), which had a correlation to the psychological job demands just below the cut-off point of $0.3(0.286)$. Nevertheless, like all the others, even this item had a significant correlation at 0.01 level. The inter-correlation of the four scales, although being significant $(p<0.01)$, tended to be weak (below 0.30). The exceptions were decision latitude/supervisor support (0.355), and supervisor support/co-worker support (0.335). Moreover, the correlations between the decision latitude scale and its subscales $(\mathrm{DL} / \mathrm{SD}=0.98, p<0.01 ; \mathrm{DL} / \mathrm{DA}=0.76$, $p<0.01)$ and between the two subscales $(\mathrm{r}=0.62$, $p<0.01)$ were very high, showing, as expected, a strong relation between the three scales.

Three Cronbach's alpha coefficients indicated an adequate consistency: decision latitude (0.74), and social support from supervisor (0.89) and co-workers (0.85), the two latter being fairly high. The psychological job demands scale had a very low reliability $(0.48)$.

\section{Discussion}

The purpose of the study was to evaluate the psychometric properties of the Portuguese version of 22item JCQ and to contribute to the discussion about the decision latitude's division in one or two dimensions and the adequacy of the psychological job demand's items.

The correlation between scales tended to be weak but significant, which indicates that they are fairly independent concepts, but there is a relation between them. In other words, there is only minimal overlap in what the scales are measuring. Nevertheless, the correlation among the supervisor and co-worker support scales was positive and substantial, as it was found on most studies (Niedhammer, 2002; Niedhammer et al., 2006; Pelfrene et al., 2001). For example, Karasek et al. (1998), analyzing several studies, stated that the mean coefficient was 0.40 . Given all these results, some authors think that they should be considered as two subscales from a social support scale (Kawakami et al., 1995; Niedhammer et al., 2006; Pelfrene et al., 2001). The correlation between decision latitude and supervisor support was positive and strong. Pelfrene et al. (2001) also found a high correlation. Niedhammer (2002) and Li, Yang, Liu, Xu, and Cho (2004) reached similar conclusions. The correlation between psychological job demands and decision latitude was low, which supports the relative independence, theoretically postulated, of the two dimensions of the model.
Other studies tend to indicate the same (Araújo, \& Karasek, 2008; Brisson et al., 1998; Karasek et al., 1998; Li et al., 2004; Niedhammer, 2002; Pelfrene et al., 2001; Sale, \& Kerr, 2002). The found correlation between decision latitude and co-worker support was low. The weak correlations found between the psychological job demands scale and the supervisor or co-worker support scales were also shown in other studies (Niedhammer, 2002; Pelfrene et al., 2001), but in some of them the correlation was negative, mainly between the psychological job demands scale and the supervisor support scale (Niedhammer, 2002; Niedhammer et al., 2006).

As expected, the decision latitude correlated very strongly with its subscales (skill discretion/decision authority), and the correlation between the two subscales was also strong. Brisson et al. (1998), Karasek (1979), Karasek et al. (1998), Landsbergis et al. (1992), Niedhammer (2002), Niedhammer et al. (2006), and Storms et al. (2001) tend to find strong correlation between the two subscales of decision latitude as well.

Three of the scales showed acceptable (decision latitude), or good levels of internal consistency (supervisor support and co-workers support). The values were similar to those obtained in other studies all around the world (Niedhammer 2002; Niedhammer et al., 2006; Phakthongsuk, \& Apakupakul, 2008). The psychological job demands scale had an unacceptable level of internal consistency (0.48). The psychological job demands scale, especially the one with five questions, tends to have borderline alpha values, but there are some studies that show completely inadequate values (Amin, Quek, Oxley, Noah, \& Nordin, 2015; Araújo, \& Karasek, 2008; Hadi, Naing, Daud, \& Nordin, 2006; Li et al., 2004; Mausner-Dorsch, \& Eaton, 2000; Phakthongsuk, \& Apakupakul, 2008). Karasek et al. (1998) reviewed six studies from America, Europe and Asia and concluded that, indeed, the psychological job demands scale, with five questions, showed poor internal consistency. Araújo and Karasek (2008), in an adaption to Brazilian population, also concluded that "these results revealed a general imprecision of the job content questionnaire in measuring psychological demand" (Araújo, \& Karasek, 2008, p. 57).

To some authors, the five questions of this scale might not be sufficient to measure the various psychological job demands in the workplace and it needs to be modified to improve the scale reliability (Phakthongsuk, \& Apakupakul, 2008). Pelfrene et al. (2001) report that the scale should comprehend a clear distinction between "qualitative" and "quantitative" psychological job demands. They also refer the suggestion to include emotional demands. Other authors, like Karasek et al. (1998), have argued that different populations can give different meanings to 
psychological job demands, which could explain part of these results.

With an initial exploratory factor analysis, all items from the two social support scales loaded in the expected factors (factors 2 and 3 ), and the majority of items from the decision latitude and psychological job demands scales loaded in the expected factors (factors 1 and 4). Nevertheless, there are four items that loaded in two factors not foreseen by the theory: two from the decision latitude scale ("repetitive work" and "lot to say" - factor 6), and two from the psychological job demands scale (factor 5 - "no excessive work" and "work hard", the latter also loaded in the factor 4 , as expected). The decision latitude scale items loaded in two factors, but they were not those expected from theory. Five items from skill discretion subscale and two from decision authority loaded in one factor, and one item from each subscale loaded in the other factor. In fact, the theoretical division between skill discretion and decision authority is not always found: some investigations identify two factors (Karasek et al., 1998; Smith et al., 1997) and others one (Niedhammer et al., 2006; Pelfrene et al., 2001; Phakthongsuk, \& Apakupakul, 2008).

When a four-factor structure was forced, the results were more similar to those expected: each factor tended to correspond to a scale. However, there were two items, ("repetitive work" and "no excessive work"), that did not load in any factor, and one item ("work hard"), that loaded in two factors (decision latitude and psychological job demands). When those items were deleted, the exploratory factor analysis (without any pre-determined factor number) found a perfect four-factor model, and each factor corresponded to a scale. As the removal of those items increases scales reliability and leads to a stronger factor structure, it seems recommended to delete them.

Many studies also pointed to problems with the "repetitive work" item: it did not load on the decision latitude factor or in any other factor (Araújo, \& Karasek, 2008; Kawakami et al., 1995; Niedhammer, 2002; Niedhammer et al., 2006; Ortiz, 2011; Pelfrene et al., 2001; Phakthongsuk, \& Apakupakul, 2008; Mausner-Dorsch, \& Eaton, 2000; Smith et al., 1997). In fact, in an international study (Karasek et al., 1998), the "repetitive work" was the most troublesome item consistently found. Some authors think that those results could be related to a non-normal distribution of this dimension (Karasek et al., 1998), with the repetitive work being much more frequent in some professions (like the lowest skilled workers). Other authors (Mausner-Dorsch, \& Eaton, 2000) justified the item low correlation with the scale saying that the repetitiveness of work is no longer perceived as lack of skill discretion, but rather as physical demand.

Brisson et al. (1998), in France, also found some problems with the item "work hard", because it loaded in two factors (psychological job demands and decision latitude). In that French version, as in the Portuguese version, the word mentally ("work hard mentally") was added to the item, thus intending to ensure that the item evaluates psychological demands and not the physical exertion (which is another scale of the JCQ). Nevertheless, this alteration could have changed the item's meaning.

Other investigations found difficulties with the grouping of the item "excessive work": the item loaded in a dissimilar factor from those of its scale (Araújo, \& Karasek, 2008; Karasek et al., 1998; Phakthongsuk, \& Apakupakul, 2008), or had low factor loadings in every factor (Niedhammer, 2002).

In conclusion, the results of the Portuguese JCQ version scales reliability and the factorial analysis are generally supportive of the job demand-control-support model. The same strengths and weaknesses of the model as observed elsewhere also tend to be observed in this study: "All of the JCQ assessments have generally found acceptable validity and substantial comparability of the JCQ scales across populations, albeit with some significant exceptions, as in the case of the psychological job demands scale" (Karasek, Choi, Ostergren, Ferrario, \& De Smet, 2007, p. 190). Therefore, the findings of this study indicated that the Portuguese JCQ version is fairly reliable and valid for assessing psychosocial work conditions among Portuguese working people, mainly in the white-collar occupations, and can help Portuguese researchers and clinicians to appropriately evaluate job strain in Portugal.

To improve the scale's internal consistency and have a stronger factorial structure, we recommend the deletion of three items: "repetitive work", "work hard", and "no excessive work". As the psychological job demands scale would only have three items, it seems important to find out new items that better assess the psychological constraints that characterize today's workplace, or changing the wording of the present ones to better explain its meaning and account for potential translation difficulties.

One limitation of this study is the sample used, because it is not representative of the Portuguese workers in terms of qualifications, the type of job and the geographical distribution of the population. People with different jobs and living in different regions can have different stress levels or different sources of job strain. Nevertheless, we expect that the large number of participants and the diversity of occupational groups (22) can mitigate that limitation. 


\section{References}

Alves, M. G., Chor, D., Faerstein, E., Lopes, C. S., \& Werneck, G. L. (2004). Versão resumida da "job stress scale": adaptação para o português [short version of the "job stress scale": a Portuguese-language adaptation]. Revista de Saúde Pública, 38(2), 164-71.

Amin, N.A., Quek, K.F., Oxley, J.A., Noah, R.M., \& Nordin, R. (2015). Validity and reliability of Malay version of the Job Content Questionnaire among public hospital female nurses in Malaysia. International Journal of Occupational \& Environmental Medicine, 6(4), $232-242$.

American Psychological Association. (2002). Ethical principles of psychologists and code of conduct. Washington: American Psychological Association.

Araújo, T. M., \& Karasek, R. (2008). Validity and reliability of the job content questionnaire in formal and informal jobs in Brazil. Scandinavian Journal of Work Environment and Health, 6, 52-59.

Brisson, C., Blanchette, C., Guimont, C., Dion, G., Moisan, J., Vézina, M. et al. (1998). Reliability and validity of the French version of the 18-item Karasek Job Content Questionnaire. Work \& Stress, 12, 322-336.

Chien, T.-W., Lai, W.-P., Wang, H.-Y., Hsu, S.-Y., Castillo, R. V., Guo, H.-R. et al. (2011). Applying the revised Chinese Job Content Questionnaire to assess psychosocial work conditions among Taiwan's hospital workers. BMC Public Health, 11, 478.

Choi, B. K., Bjorner, J. B., Ostergren, P., Clays, E., Houtman, I., Punnett, L. et al. (2009). Cross-language differential item functioning of the Job Content Questionnaire among European countries: the JACE study. International Journal of Behavioral Medicine, 16, $136-147$.

Choi, B. K., Kawakami, N., Chang, S. J., Koh, S. B., Bjorner, J., Punnett, L. et al. (2008). A cross-national study on the multidimensional characteristics of the five-item psychological demand scale of the Job Content Questionnaire. International Journal of Behavioral Medicine, $15,120-132$.

Damásio, B. F. (2012). Uso da análise factorial exploratória em psicologia [Use of exploratory factor analysis in psychology]. Avaliação Psicológica, 11(2), 213-228.

Edimansyah, B.A., Rusli, B.N., Naing, L., \& Mazalisah, M. (2006). Reliability and construct validity of the Malay version of the Job Content Questionnaire (JCQ). The Southeast Asian Journal of Tropical Medicine and Public Health, 37, 412-416.

Engström, M., Ljunggren, B., Lindqvist, R., \& Carlsson, M. (2006). Staff satisfaction with work, perceived quality of care and stress in elderly care: psychometric assessments and associations. Journal of Nursing Management, 14(4), 318-28.

Fransson, E., Nyberg, S. T., Heikkilä, K, Alfredsson, L., Bacquer, D. D., Batty, G. D. et al. (2012). Comparison of alternative versions of the job demand-control scales in 17 European cohort studies: the IPD-Work consortium. BioMedCentral Public Health, 12, 62.

Hadi, A. A., Naing, N. N., Daud, A., \& Nordin, R. (2006). Reliability and construct validity of the Malay version of the Job Content Questionnaire (JCQ) among secondary school teachers in Kota Bharu, Kelantan, Malaysia. The Southeast Asian Journal of Tropical Medicine and Public Health, 37, 1254-1259.

Hill, M. M., \& Hill, A. (2000). Investigação por questionário [Research by questionnaire]. Lisbon: Sílabo Editions.

Hoang, T. G., Corbière, M., Negrini, A., Pham, M. K., \& Reinharz, D. (2013). Validation of the Karasek-Job Content Questionnaire to measure job strain in Vietnam. Psychological Reports: Employment Psychology \& Marketing, 113(2), 363-379.

Hush, J. M., Michaleff, Z., Maher, C. G., \& Refschauge, K. (2009). Individual, physical and psychological risk factors for neck pain in Australian office workers: a 1-year longitudinal study. European Spine Journal, 18, 1532-1540.

Jabali, S. M. T., Ghaffari, M., Pournik, O., Ghalichi, L., Yazdi, A. R. T., \& Motevalian, S. A. (2013). Reliability and validity of Persian version of Job Content Questionnaire in health care workers in Iran. International Journal of Occupational Safety E Ergonomics, 4(2), 96-101.

Johnson, J.V., Hall, E.M., \& Theorell, T. (1989). Combined effects of job strain and social isolation on cardiovascular disease morbidity and mortality in a random sample of the Swedish male working population. Scandinavian Journal of Work Environment and Health, 15, $271-279$.

Karasek, R.A. (1979). Job demands, job decision latitude, and mental strain: implications for job redesign. Administrative Science Quarterly, 24, 285-308

Karasek, R.A. (1985). Job Content Questionnaire and user's guide. Lowell: University of Massachusetts.

Karasek, R.A., Brisson, C., Kawakami, N., Houtman, I., Bongers, P., \& Amick, B. (1998). The Job Content Questionnaire (JCQ): an instrument for internationally comparative assessment of psychosocial job characteristics. Journal of Occupational Health Psychology, 3, 322-355.

Karasek, R.A., Choi, B.K., Ostergren, P., Ferrario, M., \& De Smet, P. (2007). Testing two methods to create comparable scale scores between the Job Content Questionnaire (JCQ) and JCQ-like questionnaires in the European JACE study. International Journal of Behavioral Medicine, 14, 189-201.

Kawakami, N., Kobayashi, F., Araki, S., Haratani, T., \& Furui, H. (1995). Assessment of job stress dimensions based on the job demandscontrol model of employees of telecommunication and electric power companies in Japan: reliability and validity of the Japanese version of the Job Content Questionnaire. International Journal of Behavioral Medicine, 2, 358-375.

Lange, A. H., Taris, T. W., Kompier, M. A. J., \& Houtman, I. L. (2003). "The Very Best of the Millennium": longitudinal research and the demand-control-(support) model. Journal of Occupational Health Psychology, 8(4), 282-305.

Landsbergis, P. A., Schnall, P. L., Dietz, D., Friedman, R., \& Pickering, T. G. (1992). The patterning of psychological attributes and distress by job strain and social support in a sample of working men. Journal of Behavioral Medicine, 15, 379-405.

Li, J., Yang, W., Liu, P., Xu, Z., \& Cho, S. I. (2004). Psychometric evaluation of the Chinese (mainland) version of Job Content Questionnaire: a study in university hospitals. Industrial Health, 42, 260-267.

Mausner-Dorsch, H., \& Eaton, W. W. (2000). Psychosocial work environment and depression: epidemiologic assessment of the demandcontrol model. American Journal of Public Health, 90, 1765-1770.

Maroco, J. (2003). Análise estatística com utilização do SPSS [Statistical analysis using the SPSS]. Lisbon: Sílabo Editions.

Niedhammer, I. (2002). Psychometric proprieties of the French version of the Karasek Job Content Questionnaire: a study of the scales of decision latitude, psychological demands, social support, and physical demands in the GAZEL cohort. International Archives of Occupational Environmental Health, 75, 129-144.

Niedhammer, I., Chastang, J.-F., Gendrey, L., David, S., \& Degioanni, S. (2006). Propriétés psychométriques de la version française des échelles de la demande psychologique, de la latitude décisionnelle et du soutien social du "Job Content Questionnaire" de Karasek: Résultats de l'enquête nationale SUMER [Psychometric properties of the French version of the scales of psychological demands, decision latitude and social support of the "Job Content Questionnaire" Karasek: results of national survey SUMER]. Santé Publique, $18,413-427$. 
Nunnally, J. C., \& Bernstein, I. H. (1994). Psychometric theory. 3rd edition. New York: McGraw-Hill.

Ortiz, V. G. (2011). Assessment of psychological stressors at work: psychometric properties of the JCQ in Colombian workers. Revista Lationamericana de Psicologia, 43, 329-342.

Pelfrene, E., Vlerick, P., Mak, R. P., De Smet, P., Kornitzer, M., \& De Backer, G. (2001). Scale reliability and validity of the Karasek 'job demand-control-support' model in the Belstress study. Work \& Stress, 15, 297-313.

Phakthongsuk, P., \& Apakupakul, N. (2008). Psychometric properties of the Thai version of the 22-item and 45-item Karasek Job Content Questionnaire. International Journal of Occupational Medicine and Environmental Health, 21, 331-344.

Sale, J. E. M., \& Kerr, M. S. (2002). The psychometric proprieties of Karasek's demand and control scales within a single sector: data from a large teaching hospital. International Archives of Occupational Environmental Health, 75, 145-152.

Sanne, B., Mykletum, A., Dahl, A. A., Moen, B. E., \& Tell, G. S. (2005). Testing the job demand-control-support model with anxiety and depression as outcomes: the Hordaland Health Study. Occupational Medicine, 55, 463-473.

Santavirta, N. (2003). Construct validity and reliability of the Finnish version of the demand-control questionnaire in two samples of the 1,028 teachers and 630 nurses. Educational Psychology, 23(4), 423-436.

Smith, C. S., Tisak, J., Hahn, S.E., \& Schmieder, R.A. (1997). The measurement of job control. Journal of Organizational Behavior, $18,225-237$.

Stansfeld, S., \& Candy, B. (2006). Psychosocial work environment and mental health: a meta-analytic review. Scandinavian Journal of Work Environment Health, 32, 443-462.

Storms, G., Casaer, S., De Wit, R., Van Den Bergh, O., and Moens, G. (2001). A psychometric evaluation of a Dutch version of the Job Content Questionnaire and of a Short Direct Questioning procedure. Work \& Stress, 15(2), 131-143.

Van der Doef, M., \& Maes, S. (1999). The job demand-control (-support) model and psychological well-being: a review of 20 years of empirical research. Work \& Stress, 13, 87-114.

Zotnierczyk-Zreda, D. \& Bedyriska, S. (2014). Psychometric proprieties of the Polish version of Karasek's Job Content Questionnaire. International Journal of Occupational Safety E Ergonomics, 6(4), 583-593.

\section{About the authors}

Madalena Vilas-Boas has a Bachelor's degree in psychology, a MBA and a PhD in Management. She has 28 years of work experience in business context as consultant. She teaches Human Resource Management and Organisational Behaviour courses. Her main research areas of interest are strategic human resource management, workplace mobbing, leadership, motivation, and stress.

Alzira Cerqueira has a Bachelor's and Master's degree in Social and Work Psychology. Over 40 years of professional experience, she has developed activities in several areas of management, mainly at the level of Top Management, in the fields of communication and human resource management. Her main research interests are stress in an organizational context and in a general context of everyday life. 